\title{
Use of Cooperative Learning Methods STAD Strategies to Improve students' Abilities in Qira'ah (Experimental Research in Ma'had al-Uluum ad-Diniiyati al-Islaamiyyati Samalanga)
}

\author{
Murdani, Mahdir Muhammad, Bani Amin, Mira Ulfa, Muhammad Haikal \\ Institut Agama Islam (IAI) Al-Aziziah Samalanga Bireuen \\ tgkmurdanilancok@gmail.com
}

\begin{abstract}
Qira'ah is one of the four language skills, even it is the biggest intermediaries to get knowledge, either shari'a or general. Teachers in salafiah colleges using classical methods in the teaching of Qira'ah in which teachers are more involved and the lack of attention, activity and creativity of students, so the ability to read correctly the students Less increase. And because the teachers need to be more suitable methods, one of which is a cooperative learning STAD. This research was conducted in ma'had al-uluum ad-diniiyati alislaamiyyati Samalanga. The population is all students in second class ma'had al-uluum addiniiyati al-islaamiyyati Samalanga and the sample was second H class totaling 34 students and second I class was 34 students. The purpose of this research was to know the effectiveness of using in Ma'had al-uluum ad-diniiyati al-islaamiyyati Samalanga. This research is an experimental research. The results showed that the application of cooperative learning STAD qiraah was effective in improving the ability of students, it can be seen from the t-hitung is bigger than t-table, that is 2.83>1.99.
\end{abstract}

Keywords : Cooperative Learning Method; STAD strategy; Qira'ah

\section{Introduction}

The Qur'an is the first source of law in Islam, and Hadith is the second source of Islamic law. Both written in Arabic and Islam can only be known by understanding both. Islam is very concerned about the Qur'an and hadith, and Muslims must learn both to help them understand Islam. Arabic has spread throughout the world and has been taught everywhere to become the second international language after English and now people need to interact with Arabic every day.

Most thinkers are interested in reading subjects and educational poles and great people because it is a subject related to each subject in the field of education, and it is one of the best topics that can expand students' linguistic information and increase their history and geographical knowledge and practical and strengthen their moral, technical and national tendencies. Therefore, no other subject has the benefit of research and supervision because it teaches reading, not only at the primary stage, but at various stages of study.

Researchers believe that learning to read is needed for students to understand language through written symbols. Reading is also the first step to getting language science followed by listening, which is the second step to expressing the first step which is one component of language skills. One of the aims of Qira-ah teaching is to understand the understanding of Arabic texts with their meanings from Arabic books.

Ma'had al-Uluum ad-Diniiyati al-Islaamiyyati Samalanga is one of the most famous Islamic boarding schools in Aceh. This pesantren focuses on students' ability to read Arabic books and understand their meanings. Among the Arabic-language books that students learn at this institution are such as the books of jurisprudence, hadith, Arabic grammar, interpretation, Tawheed, Balaghah and others. Reading is an important matter in the activities 
of the teaching and learning process in obtaining extensive information such as references written in Arabic as intended by the author which is an important means to understand the knowledge of Islam, the Quran and Hadith.

Teachers in the teaching process at this institution use Arabic grammar and translation methods, where teachers are more active in learning compared to students. And there are still some students who have not been able to read Arabic books properly and correctly, even though they have learned Arabic from morning, afternoon to night for two years, even more. Therefore, researchers believe that the teaching and learning process of reading in this institution needs to enrich learning methods that are appropriate to the learning objectives. One of them is by applying the STAD type of cooperative learning method. Because this method makes it easy for students to study together with their friends in one group.

\section{Theory of Literature}

\subsection{Definition of Cooperative Learning}

According to Johnson in B. Santoso Cooperative Learning is teaching and learning activities in small groups, students learn and work together to arrive at an optimal learning experience, both individual and group experiences. Whereas Nurhadi defines Cooperative Learning as learning that consciously and intentionally develops interactions that are fostered to avoid offense and misunderstandings that can cause problems.

Furthermore, Davidson and Kroll, as quoted by Hamdun, Cooperative Learning is defined as activities that take place in a learning environment so students in small groups share ideas and work collaboratively to complete academic tasks.

As a result, Cooperative Learning is a learning method based on group work carried out to achieve specific goals. In addition to solving problems in understanding a concept based on a sense of responsibility and the view that all students have the same goal. Communicative and interactive student learning activities occur in small groups.

Therefore, according to Melvin L. Silberman, as quoted by Sutrisno, said learning is an automatic consequence of delivering information to students. Learning requires mental involvement and action at once. When the activity is active, students do most of the learning work. Students learn ideas, solve problems and apply what they learn

By using the Cooperative Learning method, learning will be effective and run according to the nature of students as social beings, namely creatures that cannot stand alone, but always need collaboration with others to learn ideas, solve problems and apply what they learn. Clearly, cooperative learning is not only aimed at instilling students in the material to be learned, but more emphasis on training students to have social abilities, namely the ability to work together, group and be responsible for fellow group members to achieve the group's general goals.

Cooperative Learning methods are built on the basis of the Social Constructivists of Vygotsky, the Personal Constructivist theory of Piaget and the Theory of Motivation. According to the main principles of Vygotsky's theory, the development of thought is a social process from birth. Children are assisted by others (both adults and peers in groups) who are more competent in their skills and technology in their culture. For Vigo sky, collaborative activities among children will support their growth, because suitable children prefer to work with people who are in one zone (Zone of Proximal Development, ZPD) with others. On this view, the personality or psychology of the participants is observed in its entirety, meaning that 
the psychological elements or parts do not stand alone, but are organized into a whole. Therefore, it is not surprising that Cooperative Learning is very holistic rather than a small part of the learning process that prioritizes group work.

In simple terms Constructivism theory assumes that knowledge is a construction of knowing something. Our knowledge is not a fact that remains to be found, but a formulation or formulation created by someone who learns it. 8 Constructivism Theory does not aim to understand reality, but rather see how a process, in this case is learning, from not knowing to knowing something that is. So in this view learning is an active process of students to construct meaning, physical experience and so on.

While Piaget also saw the importance of social relations in shaping knowledge.9 Group interactions differ qualitatively and are also stronger than the interactions of adults and children in facilitating cognitive development. Piaget's theoretical position in cooperative learning is aimed primarily at highly capable students to be able to build their own knowledge through interaction with the environment. Because, human environment and physical environment are sources that influence the personality development and abilities of students. Thus he was able to become a scaffolding for his other friends.

According to the motivation theory proposed by Slaving, learning motivation in cooperative learning is primarily focused on the appreciation of the objective structure in which students move. According to this view, giving awards to groups based on group appearance will create a reward structure between individuals in a group so that group members give each other social reinforcement as a response to group-oriented efforts.

Cooperative Learning methods are applied through small groups on all subjects and the age level is adjusted to the conditions and learning situations. Group membership consists of different (heterogeneous) students both in academic ability, gender and ethnicity, social and economic background. In terms of academic ability, Cooperative Learning groups usually consist of one highly capable person, two people with moderate abilities and one other from a group of less academic abilities. Cooperative Learning aims to communicate students 'learning, avoid students' attitude of competition and sense of individuality, especially for students who are low and high achievers.

\subsection{Cooperative Learning Elements}

According to Roger and David Johnson in Anita Lie, not all group work can be considered Cooperative Learning. To obtain the expected benefits of implementing cooperative learning, Johnson and Johnson suggest five important elements that must be built into instructional activities, including:

a. Positive Interdependence (Positive Interdependence)

Positive Interdependence (Positive Interdependence) The success of a group is very dependent on the efforts of each member. To create an effective working group, the teacher needs to arrange the task in such a way that each group member must complete his or her own task so that others can achieve their goals. In the Jigsaw method, Aronson suggested that the number of group members is limited to only four people and the four members were assigned to read different sections. These four members then gather and exchange information. Next, the teacher will evaluate them about all parts. In this way, each member feels responsible for completing his task so that others can succeed.

b. Face to Face Interaction (Face to Face Interaction) 
Each group must be given the opportunity to meet face to face and discuss. This interaction activity will provide learners to form synergies that benefit all members. The results of the thoughts of some people will be richer than the thoughts of one person. Furthermore, the results of this collaboration are far greater than the number of results of each member. And this face-to-face interactive activity will also have implications for interpersonal intelligence between fellow members or opponents face to face. This process can be presented with group work or the formation of small groups to achieve the objectives of general learning or Islamic education in particular. The essence of this synergy is respecting differences, utilizing strengths and filling in the shortcomings of each. (Thomas Armstrong: 2004, 121)

c. Individual Accountability (Individual Accountability)

This element is a direct result of the first element. If assignments and assessment patterns are made according to the Cooperative Learning model procedure each student will feel responsible for doing their best. The key to the success of group work methods is the preparation of the teacher in arranging the task. In the Jigsaw technique, the reading material is divided into four parts and each learner gets and reads one part. In this way, learners who do not carry out their duties will know clearly and easily. His colleagues in one group can help and provide encouragement to understand the material and will demand to carry out their duties so as not to inhibit the others. This is in line with the details of Imam and Taqwa by Djamaluddin and Abdullah Aly in his book "Kapita Selekta Islamic Education", which is wrong with the unit is to have social and national responsibility. (Djamaluddin and Abdulllah Aly: 1999, 41)

d. Social Skills (Social skills),

What is meant by social skills is skills in communicating in groups. Before assigning students in groups, teachers need to teach ways of communicating. Not every student has listening skills and the ability to express their opinions. Sometimes learners need to be told explicitly about ways to communicate effectively such as how to refute other people's opinions without having to offend the person.

e. Group process evaluation (Group Debriefing)

Teachers need to schedule specific times for groups to evaluate the group work process and the results of their collaboration so that they can work together more effectively. The time of this evaluation does not need to be held every time there is group learning, but it can be held several times after several times learning is involved in learning activities. This will bring personal skills (personal skills), which include skills regarding self (self-awareness) and rational thinking skills (thinking skills). Self-skill is basically a self-appreciation as God Almighty, members of society and citizens, and is aware of and grateful for the advantages and disadvantages that are possessed, while making them as individuals who benefit themselves and their environment. (Team Broad Based Education: tt, 10)

\subsection{Techniques in Cooperative Learning}

There are several techniques in the Cooperative Learning method. Nevertheless the teacher does not have to be fixated on just one strategy. The teacher can choose and modify the techniques in the Cooperative Learning method according to the class situation. In one hour / session, the teacher can also use more than one technique.

Here are some learning techniques in Cooperative Learning:

a. Jigsaw 

b. Group Investigation
c. Numbered Head Together
d. Think-Pair-Share (Thinking-Pair-Four)
e. STAD (Student Team Achievement Division)

\subsection{Strengths and Weaknesses of Cooperative Learning}

Cooperative learning has several advantages. The advantages of cooperative learning according to Hill \& Hill (1993: 1-6) are (1) increasing student achievement, (2) deepening student understanding, (3) pleasing students, (4) developing leadership attitudes, (5) developing positive student attitudes, (6) develop self-respect, (7) make learning inclusive, (8) develop a sense of belonging, and (9) develop skills for the future.

Besides having advantages, cooperative learning also has several weaknesses. According to Dess (1991: 411) some disadvantages of cooperative learning are (1) requires a long time for students, so that it is difficult to achieve curriculum targets, (2) takes a long time for teachers so most teachers do not want to use cooperative strategies, (3) need teacher's special abilities so that not all teachers can do or use cooperative learning strategies, and (4) demand certain characteristics from students, for example the nature of cooperating

\subsection{Cooperative Learning Type STAD Learning}

STAD was developed by Robert Slavin and his friends at John Hopkin University. Teachers who use STAD also refer to student group learning every week using verbal and text presentations. In one group students consisted of 4-5 heterogeneous people. Team members use another activity sheet or learning tool to complete the material and then help each other to understand the lesson material through tutorials, quizzes or discussions. Individually every week students are given a quiz. The quiz is scored and each individual is given a development score. (Muslim Ibrohimin: 2000, 20)

\subsection{Steps of Cooperative Learning Learning Type STAD}

a) Students are divided into small groups consisting of (4-5) members who have heterogeneity abilities

b) The teacher gives the subject matter that will be studied by students, so that students can look for the information that will be discussed in the lesson (Before learning)

c) The teacher begins the lesson by presenting the material to be discussed in advance. The material presented is not comprehensive only the subject matter and ends with a number of questions that must be discussed by students in the youth group.

d) The teacher provides a student worksheet that matches the material and the teacher tells them that the worksheet will be collected after they have finished working on and understanding it.

e) Students discuss answers from teacher questions with friends in one study group

f) The teacher goes around becoming a facilitator in student learning group discussion activities

g) After the group discussion activities the teacher finished giving a quiz to measure the extent of students' understanding of the material that had been discussed

h) The teacher checks the results of the quiz and gives awards to students and groups who answer correctly and give appreciation to all students and other groups to be more motivated. 


\subsection{Characteristics of STAD Learning Cooperative Learning Methods}

There are several characteristics of the STAD learning method. They are:

a) Students work in groups to complete material

b) Each group consists of students with high, medium and low potential

c) Group members must be of various sexes, ethnicities, and social statuses

d) Prioritizing giving appreciation to groups compared to individuals (Rusmansyah: 2006)

\subsection{Elements of the Stad Type Learning Cooperative Learning Method}

a) Group members Understand they live together

b) Group members have one goal

c) Group members must share the same duties and responsibilities among fellow members

d) Group members have one scadul

e) Obtaining the same duties and responsibilities among group members among fellow members (Rusmansyah: 2006)

\subsection{The advantages of the STAD type of Cooperative Learning Learning Method Are:}

a) Develop individual skills

b) Develop group skills

c) Increase commitment and optimism

d) Tolerance towards others

e) There is no individual selfish feeling among students

f) The ability to grow good relationships

g) Increase motivation to learn

h) Help each other solve problems.

i) Help each other in understanding the material to resolve difficulties (Imal Tapan: 2011)

\subsection{Weaknesses of Cooperative Learning Learning Methods STAD Type:}

a) Students who are less intelligent and less diligent will feel pessimistic about smarter friends

b) Class situations look so quiet that students cannot work effectively in groups

c) Spend a lot of time

\subsection{Reading Qira'ah}

In the view of experts, in general reading learning consists of two types, namely reading aloud and reading silently. Other types of reading are part of the type of reading in the heart. (Walid Ahmad Jabir, 2002: 49)

a. Reading aloud (Qira'ah Jahriyah)

Reading aloud is a skill that must get serious attention in the learning process. because, it is the foundation for achieving all reading skills competencies Reading aloud trains the pronunciation of words clearly so students can connect between the graphic symbols and their ponetis.

- The purpose of reading aloud (Qira'ah Jahriyah)

a) Train students to get used to pronouncing letters, words, phrases and sentences according to the rules of Arabic sound. 
b) Train students to read with the intonation and rhythm that corresponds to the type of sentence and the content of the meaning.

c) Train students for expressive reading that shows their understanding of the text being read.

d) Train students to pay attention to punctuation.

- Strength of reading aloud (Qira'ah Jahriyah)

Reading aloud is the best technique for practicing fluency in pronunciation, performance in reading, and expressing meaning especially for beginner students. Reading aloud also makes it easier for teachers to monitor pronunciation errors for students so they can correct them immediately. Reading aloud also trains students to get used to preparing for certain professions such as news readers, lecturers, poetry readers, and radio and television broadcasters. (Abdul 'Alim Ibrahim, tt: 70)

- As for the lack of loud reading (Qira'ah Jahriyah)

a) Reading aloud requires more energy than reading silently, because the reader is required to make a loud noise.

b) The level of understanding gained from reading aloud is lower than reading inwardly.

c) Reading that is popular in everyday life is reading inwardly rather than reading aloud.

d) Reading aloud causes noise and can disturb others.

b. Reading in the Heart (Qiro'ah Shamitan)

Reading in the heart is reading that is done only by using the eyes without sound or whisper, without even moving the lips. The main purpose of reading inwardly is mastery and understanding, both global understanding and details. (Ahmad Fuad Effendi, 2004: 124)

The main element of reading in the heart is understanding and speed. Therefore, students must be trained to master and understand the material they read by paying attention to speed in reading.

Reading in the heart has several foundations both psychologically, sociologically, and physiologically. Psychologically, reading in the heart can provide calm and at the same time cover the shortcomings of the words that the reader has. Reading in the heart can also increase concentration, so that the reading content can be absorbed properly. Sociologically, reading inwardly respects the feelings of others, even if the reading activity is carried out in the publicly provided reading room.

Physiologically, reading silently gives the opportunity for the utterance member to rest. Reading this type can also ease the burden on the eyes that do not need to pay too much attention to words and sentences.

\section{Research Method}

This study uses a type of quantitative research with an Experimental approach. Experimental Approach (Experimental Research) is a research activity that aims to assess the effect of a treatment / action / educational treatment on student behavior or test hypotheses about whether or not there is an effect of that action when compared to other actions (supardi: 2007). 
The population is all class II students in the 2015/2016 academic year at the Ma'hadal 'Ulum Diniyah Islamiah (MUDI) boarding school in the Samalanga Grand Mosque. While the sample is class II / H as many as 34 people and class II / I as many as 34 people. Through purposive sampling technique while the research instruments used are observations, tests, and documentation

\section{Results and Discussion}

Student achievements in the use of STAD learning at the Ma'hadal um Ulum Diniyah Islamiah (MUDI) pesantren in the Samalanga Grand Mosque. This field research uses essay tests to identify student responses to STAD type group learning in teaching reading. The response in this way is to provide students with incentives and assimilation on their own development and the formation of their concepts to attract the results available in the reading for the study of Arabic. Test questions for students in the experimental group consist of 3 types: Formation, Correct, False, and Duplicating in 30 questions. And carried out by researchers before using the STAD method and after use.

Table 1. Student Values in Experimental Groups

\begin{tabular}{|c|c|c|c|c|c|}
\hline \multirow{2}{*}{ No } & \multicolumn{2}{|c|}{ Pre-test } & \multicolumn{2}{c|}{ Post-test } & \multirow{2}{*}{ Result } \\
\cline { 2 - 5 } & Student Name & Score & Student Name & Score & \\
\hline 1 & Student 1 & 73 & Student 1 & 77 & 4 \\
\hline 2 & Student 2 & 73 & Student 2 & 77 & 4 \\
\hline 3 & Student 3 & 72 & Student 3 & 77 & 5 \\
\hline 4 & Student 4 & 79 & Student 4 & 83 & 4 \\
\hline 5 & Student 5 & 80 & Student 5 & 87 & 7 \\
\hline 6 & Student 6 & 71 & Student 6 & 77 & 6 \\
\hline 7 & Student 7 & 94 & Student 7 & 97 & 3 \\
\hline 8 & Student 8 & 92 & Student 8 & 97 & 5 \\
\hline 9 & Student 9 & 70 & Student 9 & 77 & 7 \\
\hline 10 & Student 10 & 79 & Student 10 & 83 & 4 \\
\hline 11 & Student 11 & 70 & Student 11 & 77 & 7 \\
\hline 12 & Student 12 & 68 & Student 12 & 73 & 5 \\
\hline 13 & Student 13 & 80 & Student 13 & 87 & 7 \\
\hline 14 & Student 14 & 70 & Student 14 & 70 & 0 \\
\hline 15 & Student 15 & 69 & Student 15 & 70 & 1 \\
\hline 16 & Student 16 & 76 & Student 16 & 83 & 7 \\
\hline 17 & Student 17 & 85 & Student 17 & 93 & 8 \\
\hline 18 & Student 18 & 75 & Student 18 & 80 & 5 \\
\hline 19 & Student 19 & 66 & Student 19 & 67 & 1 \\
\hline 20 & Student 20 & 85 & Student 20 & 90 & 5 \\
\hline 21 & Student 21 & 67 & Student 21 & 67 & 0 \\
\hline 22 & Student 22 & 89 & Student 22 & 93 & 4 \\
\hline 23 & Student 23 & 75 & Student 23 & 80 & 5 \\
\hline 24 & Student 24 & 68 & Student 24 & 73 & 5 \\
\hline 25 & Student 25 & 73 & Student 25 & 83 & 10 \\
\hline 26 & Student 26 & 88 & Student 26 & 90 & 2 \\
\hline 27 & Student 27 & 72 & Student 27 & 70 & $2-$ \\
\hline 28 & Student 28 & 80 & Student 28 & 87 & 7 \\
\hline
\end{tabular}




\begin{tabular}{|c|c|c|c|c|c|}
29 & Student 29 & 62 & Student 29 & 67 & 5 \\
\hline 30 & Student 30 & 71 & Student 30 & 77 & 6 \\
\hline 31 & Student 31 & 92 & Student 31 & 97 & 5 \\
\hline 32 & Student 32 & 76 & Student 32 & 80 & 4 \\
\hline 33 & Student 33 & 75 & Student 33 & 83 & 8 \\
\hline 34 & Student 34 & 71 & Student 34 & 77 & 6 \\
\hline Summary & $\mathbf{2 5 8 6}$ & Summary & $\mathbf{2 7 4 6}$ & $\mathbf{1 6 0}$ \\
\hline & Score & $\mathbf{7 6 , 0 5}$ & Score & $\mathbf{8 0 , 7 6}$ & $\mathbf{4 , 7 1}$ \\
\hline
\end{tabular}

The table above shows that when the researcher pre-tests the experimental group, the result score is 2586 with an average value of 76.05 while the post-ters results using the STAD Type Cooperative Learning method are 2746 with an average value of 80.76 and show that the value has changed by $4.71 \%$.

Explanation For the control group the author uses the formula:

Data analysis for the control group, researchers used the following formula:

1. Range $(\mathrm{R}) \quad=$ Highest score - lowest score

$=97-57$

$=40$

2. Class Number $=1+(3,3) \log n$

$=1+(3,3) \log 34$

$=1+(3,3) 1,5$

$=1+4,8$

$=5,8$

3. Class Length $=\frac{\text { Range }}{\text { Class Number }}=\frac{R}{K}=\frac{40}{5,8}=6,8$ (Rounder to 7)

Results of Frequency Distribution of Students in the Control Group

\begin{tabular}{|c|c|c|c|c|c|}
\hline Result & $f_{i}$ & $x_{i}$ & $x_{i}{ }^{2}$ & $f_{i} x_{i}$ & $f_{i} x_{i}{ }^{2}$ \\
\hline $63-57$ & 2 & 60 & 3.600 & 120 & 7.200 \\
\hline $70-64$ & 9 & 67 & 4.489 & 603 & 40.401 \\
\hline $77-71$ & 14 & 74 & 5.476 & 1.036 & 76.664 \\
\hline $84-78$ & 3 & 81 & 6.561 & 243 & 19.683 \\
\hline $91-85$ & 1 & 88 & 7.744 & 88 & 7.744 \\
\hline $98-92$ & 5 & 95 & 9.025 & 475 & 45.125 \\
\hline Total & $\mathbf{3 4}$ & & & $\mathbf{2 . 5 6 5}$ & $\mathbf{8 1 7 . 1 9 6}$ \\
\hline
\end{tabular}

From the table the value is obtained

$\overline{\mathrm{X}}_{2}=\frac{\sum f_{i} x_{i}}{\sum f_{i}}$

$\overline{\mathrm{X}}_{2}=\frac{2.565}{34}$

$\overline{\mathrm{X}}_{2}=75,44$

The Standard Deviation is as follows:

$S_{2}^{2}=\frac{n \sum f_{i} x_{i}^{2}-\left(\sum f_{i} x_{i}\right)^{2}}{n(n-1)}$

$S_{2}^{2}=\frac{34(196.817)-(2.565)^{2}}{34(34-1)}$ 
$S_{2}^{2}=\frac{6.691 .778-6.579 .225}{34(34-1)}$

$S_{2}^{2}=\frac{112.553}{1.122}$

$S_{2}^{2}=100,31$

$S_{2}=10,01$

Data analysis for the Experiment group, researchers used the following formula:

1. Range $(\mathrm{R})=$ Highest Score - Lowest Score

$=98-76$

$=30$

2. Class Number $=1+(3,3) \log n$

$$
\begin{aligned}
& =1+(3,3) \log 34 \\
& =1+(3,3) 1,5
\end{aligned}
$$$$
=1+4,8
$$$$
=5,8
$$

3. Class Length $=\frac{\text { Range }}{\text { Class Number }}=\frac{R}{K}=\frac{30}{5,8}=5,1($ Rounded to 5)

Results of Frequency Distribution of Students in the Control Group

\begin{tabular}{|c|c|c|c|c|c|}
\hline Result & $f_{i}$ & $x_{i}$ & $x_{i}{ }^{2}$ & $f_{i} x_{i}$ & $f_{i} x_{i}{ }^{2}$ \\
\hline $71-67$ & 6 & 69 & 4.761 & 414 & 28.566 \\
\hline $76-72$ & 2 & 74 & 5.476 & 148 & 10.956 \\
\hline $81-77$ & 11 & 79 & 6.241 & 869 & 68.651 \\
\hline $86-82$ & 5 & 84 & 7.056 & 420 & 35.280 \\
\hline $91-87$ & 5 & 89 & 7.921 & 445 & 39.605 \\
\hline $96-92$ & 2 & 94 & 8.836 & 188 & 17.672 \\
\hline $101-97$ & 3 & 99 & 9.901 & 297 & 29.403 \\
\hline Total & $\mathbf{3 4}$ & & & $\mathbf{2 . 7 8 1}$ & $\mathbf{2 3 0 . 1 3 3}$ \\
\hline
\end{tabular}

From the table the value is obtained

$\overline{\mathrm{X}}_{1}=\frac{\sum f_{i} x_{i}}{\sum f_{i}}$

$\overline{\mathrm{X}}_{1}=\frac{2.781}{34}$

$\overline{\mathrm{X}}_{1}=81,94$

The Standard Deviation is as follows:

$S_{1}^{2}=\frac{n \sum f_{i} x_{i}^{2}-\left(\sum f_{i} x_{i}\right)^{2}}{n(n-1)}$

$S_{1}^{2}=\frac{34(230.133)-(2.781)^{2}}{34(34-1)}$

$S_{1}^{2}=\frac{7.824 .522-7.733 .961}{34(33)}$

$S_{1}^{2}=\frac{90.561}{1.122}$ 
$S_{1}^{2}=80,72$

$S_{1}^{2}=8,98$

Data Analysis from the results of the Experiment group and the control group using the t-test, researchers used the formula:

$$
\begin{aligned}
& \mathrm{t}=\frac{\overline{\mathrm{X}}_{1}-\overline{\mathrm{X}}_{2}}{\sqrt{\left(\frac{\mathrm{s}_{1}}{\sqrt{\mathrm{N}-1}}\right)^{2}+\left(\frac{\mathrm{S}_{2}}{\sqrt{\mathrm{N}-1}}\right)^{2}}} \\
& \mathrm{t}=\frac{81,94-75,44}{\sqrt{\left(\frac{8,98}{\sqrt{34-1}}\right)^{2}+\left(\frac{10,01}{\sqrt{34-1}}\right)^{2}}}
\end{aligned}
$$

$\mathrm{t}=\frac{6,5}{\sqrt{\left(\frac{8,98}{5,74}\right)^{2}+\left(\frac{10,01}{5,74}\right)^{2}}}$

$\mathrm{t}=\frac{6,5}{\sqrt{2,47+3,07}}$

$\mathrm{t}=\frac{6,5}{\sqrt{5,54}}$

$\mathrm{t}=\frac{6,5}{2,3}$

$\mathrm{t}=2,83$

As for knowing the results of the research table using the formula:

$$
d f=n_{1}+n_{2}-2
$$

$d f=n_{1}+n_{2}-2$

$d f=34+34-2$

$d f=68-2$

$d f=66$

\section{Conclusion}

From the results of the study, the researcher obtained the ttable value at the 5\% significance level of 1.99, so the price of ttes>t table was 2.83>1.99. This indicates that the use of STAD evective type coperative learning in increasing students' ability to Qira'ah in Ma'hadal 'Ulum Diniyah Islamiah (MUDI) pesantren Samalanga Mosque.

\section{References}

Ainin, Moch, Metodologi Penelitian Bahasa Arab, Malang : Hilal Pustaka, 2007

Johnson D and Johnson R, Learning Together and Alone Boston: Allyn and Bacon, 1999

Kasiram, Moh, Teknik-Teknik Analisa Item Test Hasil Belajar dan Cara-Cara Menghitung Validity dan Reliability, Surabaya : Usaha Nasional, 1984

Matsna, Moh dan Erta Mahyudin, Pengembangan Evaluasi dan Tes Bahasa Arab, Tangerang Selatan : Al-Kitabah, 2012 
Mustafa Izzuddin, Hermawan Acep, Metodologi penelitian Bahasa Arab, 2017

Nurgiyantoro, Burhan, Statistik Terapan Untuk Penelitian Ilmu-Ilmu Sosial. Yogyakarta : Gadjah Mada University Press, 2004

Rusmansyah, Meningkatkan Hasil Belajar Siswa Melalui Model Pembelajaran Kooperatif Tipe STAD dalam Jurnal Vidya Karya, XXIV, No. 1, April 2006

Saad Ali Jaballah, Wahid Hafez, Maher Shaaban Abdel - Bari, mengajar bahasa Arab untuk orang dengan kebutuhan khusus, Kairo: Aatra K Percetakan, Penerbitan dan Distribusi 2009

Sabri, M. Alisuf, Psikologi pendidikan ,Cet I, Jakarta : Pedoman Ilmu Jaya, 1995

Supardi, Penelitian Eksperimen di Bidang Pendidikan, Jakarta : 2007 